\title{
The genetics of the butterfly Hypolimnas misippus (L.): The classification of phenotypes and the inheritance of forms misippus and inaria
}

\author{
David A. S. Smith*† and \\ Ian J. Gordon‡
}

\author{
* Department of Biology, Eton College, Windsor, \\ Berkshire SL4 6EW, England, and $\dagger$ Department of \\ Life Sciences, University of Buckingham, Buckingham \\ MK18 1EG, England. \\ $\ddagger$ Dept. of Zoology, University of Cape Coast, Ghana.
}

\begin{abstract}
Hypolimnas misippus is a polymorphic and mimetic butterfly with a pantropical distribution. The polymorphism is autosomal and female-limited, the several female forms being generally regarded as Batesian mimics of the distastefuI, toxic and polymorphic danaine butterfly Danaus chrysippus. The female phenotypes of $\boldsymbol{H}$. misippus are described and classified. New data, from the rearing of 140 broods of $\boldsymbol{H}$. misippus in Ghana and Sierra Leone, are analysed together with older material ( 21 broods) from other parts of Africa. Form misippus (genotype $M-$ ) is found to be genetically dominant to form inaria (genotype $\mathbf{m m}$ ). However, a large proportion of $\mathbf{m m}$ butterflies has an intermediate phenotype, especially in association with white on the hindwing. Evidence is adduced to show that the genes giving hindwing white are variably epistatic over the 'inaria' pattern in the $\mathbf{m m}$ genotype, producing a phenotype transitional to or even identical to misippus. The various intermediate phenotypes are poor mimics of $D$. chrysippus: their abundance, geographical range and, hence, significance have been much underestimated.
\end{abstract}

\section{INTRODUCTION}

Investigations of the genetics of mimetic polymorphisms in Papilio dardanus Brown (Clarke and Sheppard, 1959, 1960a, 1960b, 1963), Papilio glaucus (L.) (Clarke and Sheppard, 1962), Papilio memnon L. (Clarke, Sheppard and Thornton, 1968) and Papilio polytes (L.) (Clarke and Sheppard, 1972) have shown that the major forms are controlled by various combinations of alleles within a supergene. In contrast, the various forms of the polymorphic nymphalid butterfly Hypolimnas bolina (L.) (Clarke and Sheppard, 1975) are controlled at 2 or 3 loci which mainly segregate independently: although linkage between two of the loci is possible, Clarke and Sheppard did not prove it and judged it unlikely. $H$. bolina resembles the Papilios in having polymorphism restricted to the female but differs in that only one of the female forms is mimetic. Clarke and Sheppard (op. cit.) suggested that, for their generalisations to be put to a wider test, it would be necessary to investigate a genus other than Papilio, in which polymorphism

* Address for correspondence.

$\ddagger$ Present address: Department of Zoology, University of Nairobi, P.O. Box 30197, Nairobi, Kenya. for several mimetic forms occurs. We believe that Hypolimnas misippus (L.) (the diadem or danaid eggfly) is eminently suited to this purpose. It resembles $H$. bolina in its female-limited polymorphism but differs in that four, perhaps all, of its many phenotypes are credible mimics of distasteful models belonging to the Danaus chrysippus-Acraea encedon-Acraea encedana mimicry ring over much of its very extensive geographical range (Pierre, 1976, 1980).

Our principal aim in this and subsequent papers on the formal and ecological genetics of $H$. misippus is to answer the following questions:

(a) Is the detailed resemblance between mimic and model enhanced by selection for modifiers?

(b) Is the switch control for genotypes located within a supergene?

(c) Is there evidence of selection for linkage?

(d) To what extent has complete dominance evolved between sympatric forms?

(e) Is there evidence for the evolution of epistasis?

(f) How do we explain the widespread occurrence and seasonal abundance of poor mimics?

(g) Why do the mimetic forms fail to match the Danaus chrysippus (L.) model in terms both of frequency rankings and biogeography? 
H. misippus has a vast tropical and sub-tropical distribution encompassing Africa south of the Sahara, Asia, Australia, Oceania and the New World. Throughout most of its Old World range the female is generally considered to be a polymorphic Batesian mimic of the danaine butterfly $D$. chrysippus. In the New World, however, it is probably non-mimetic for it bears no more than a superficial resemblance to the American queen (Danaus gilippus Cramer) or any other neotropical danaine. The male is monomorphic, non-mimetic and quite unlike all the female forms. It closely resembles several other species of Hypolimnas, especially the male of its sister species $H$. bolina. In the Ethiopian and Oriental Regions, the female forms of $H$. misippus and their putative $D$. chrysippus models are often poorly matched with regard to sympatry, frequency rankings or phenology (Edmunds, 1969; Pierre, 1973; Smith, 1976; Gordon, 1982), anomalies which have prompted speculation that the mimetic association may be closer to Müllerian than Batesian (Poulton, 1908; Unamba, 1968; Marsh et al., 1977).

Genetical evidence has accumulated slowly and at irregular intervals over a period of 80 years (1904-83) in widely scattered parts of Africa. Due to the admirable foresight of the late Professor E. B. Poulton, the older material (1904-22) is preserved intact in the Hope Department of Entomology in Oxford. Our perusal of the Oxford collection provided the initial stimulus for further extensive breeding work which will be described here and in subsequent papers.

The new data in this paper come from two breeding programmes. The first was carried out at Freetown, Sierra Leone in 1966-68 by J. A. Unamba under the supervision of Professor D. F. Owen. Unamba died before his work could be published and Professor Owen has kindly made his results available to us. The second programme was undertaken by one of us (I.J.G.) at Cape Coast, Ghana during 1976-81. Our analysis is based on all the material available to us, 121 broods from Ghana, 19 from Sierra Leone, 4 from Kenya, 5 from Tanzania (Tanganyika), 10 from Nigeria, one from Malawi (Nyasaland) and one from Natal, Republic of South Africa, a total of 161 broods.

\section{METHODS}

Butterflies reared in Freetown (J.A.U.), Cape Coast (I.J.G.) and Dar es Salaam (Smith, 1976) were obtained by confining mated females on the foodplant, either Portulaca quadrifida L. (Portulaceae), Blepharis maderaspatensis L., Ruellia prostrata Jacq. or $R$. cordata Thunb. (all Acanthaceae), in a muslin sleeve or small cage. Most females laid over 100 eggs in 2-3 days and the maximum exceeded 550. Mean brood size (females only) was $52 \cdot 7(n=161)$, but highly skewed with a median value of 39 and a modal value of 30 .

The life cycle in the hot season at Dar es Salaam (mean ambient temperature $30^{\circ} \mathrm{C}$ ) is $2-3$ days to hatching, followed by 11 days to pupation, then 6-7 days to eclosion. The total egg to egg development time, recorded in detail for only 4 broods, averages 22.5 days for males and 23.5 days for females but the difference is not significant for this small sample. Generation times at Dar es Salaam, Freetown and Cape Coast were similar and always under one month even in the cooler seasons.

All broods were reared separately in well-ventilated cages. Some broods were ravaged or lost, mainly as a result of virus disease (Dar es Salaam) or the refusal of the larvae to eat in the dry season (Freetown). Broods with less than 8 surviving female offspring are omitted from our analysis as they yield no useful information.

It must be remembered that the male genotype cannot be inferred by inspection. As most male parents were wild, nothing is known of their genetics; a limited amount of information is available in respect of male parents from laboratory reared broods ( 61 cases) and where the same male sired more than one brood ( 8 cases). However, with simultaneous segregations occurring at several loci, and the additional complication of epistasis, the use of laboratory-bred males contributed little conclusive information. Consequently, the segregations obtained are largely deduced from the phenotypes of the female parent and her female offspring. Where two or more segregation ratios are statistically valid, the one giving the smallest value of $\chi^{2}$ is accepted: while it is clear that the method will lead to some misclassification and to an underestimate of heterogeneity, we believe that problems arising from these sources are effectively countered by the quantity and quality of the data.

Twenty-three per cent of wild females $(n=397)$ in Sierra Leone (Smith, 1984) and 5 percent in Ghana $(n=149)$ (Gordon, 1982) were found to carry two or more spermatophores so that mixed paternity may occur. However, segregations from wild mated females $(n=68)$ do not differ from those from single-mated, reared females $(n=93)$ and we suspect that sperm precedence occurs, the eggs being fertilised by the last male to copulate, as in D. chrysippus (Smith, 1984) and many other insects. 


\section{FEMALE PHENOTYPES}

Male H. misippus are monomorphic, black with three pairs of white patches, the two larger, one on each wing, ringed with irridescent purple. The female is normally, though probably not universally, polymorphic. The most widespread and generally frequent female form misippus (fig. 2) is brownish-orange except for the apical half of the forewing which is black with two white areas, the latter probably homologous with those similarly placed in the male. For analytical purposes the "misippus" forewing is divided into five areas (fig. 1): area 1 is orange, areas 2 and 4 black and areas 3 and 5 white. In conventional form inaria all the areas 1-5 are orange except for a black wing margin. Many African populations show continuous variation between the two forms, all of which is ascribable to the variable replacement of orange scales by black or white in areas 2-5. The most "misippus"-like intermediate (table 1) has black scales in area 4 mixed with orange, giving brown $(b r)$. Orange scales may invade area 3 , giving a pale orange $(p)$ colour. Areas 3 and/or 4 may be completely orange $(o)$, but not necessarily both in the same individual. When areas 3 and 4 are both orange $(o o)$, the butterfly is classified as inaria without hesitation. However, areas 2 and 5 may remain black and white respectively. In the fullest expression of the "inaria" pattern, first area 5, then area 2 , but occasionally in reverse order, are also orange.

The hindwing is also variable. Forms misippus and inaria have an entirely orange hindwing but $f$. alcippoides has a white patch, which varies in size from a small central spot, or even a few white scales, to near total displacement of orange. An additional source of hindwing variation, which is rare and occurred only in Ghanaian broods, involves a variable suffusion of the orange area by black scales: melanism occurs only in the presence of a large white patch. In heavily melanised females, the resemblance of the hindwing to that in the male is most striking.

The forewing phenotypes are described by combining the symbols $b l, b r$ and $o$ for area 4 with $w, p$ and $o$ for area 3 (Edmunds, 1969). There are seven phenotypes-blw, brw, ow, brp,op, bro and $o o$. When combined with a score $0-10$ for hindwing white, 77 phenotypes are thus specified. Adding the suffix $M$ for melanism increases the theoretical maximum to 154 but by no means all the combinations are recorded: the number of phenotypes seen by us is probably around 100 , some 60 of which occur regularly in the four African populations which have been investigated in depth.

The forewing and hindwing phenotypes frequently interact (Edmunds, 1969; Smith, 1976; Gordon, 1982). The blw ("misippus") forewing may be associated with all types of hindwing but the oo ("inaria") forewing is rarely combined with a hindwing carrying extensive white. On the other hand, there is a strong correlation between white on the hindwing and the intermediate forewing classes (see table 4). Moreover, the orange areas on the forewing of the intermediate forewing classes are often somewhat paler in association with a hindwing carrying extensive white. We hope to show in a later paper that at least some of the genes conferring hindwing white modify the
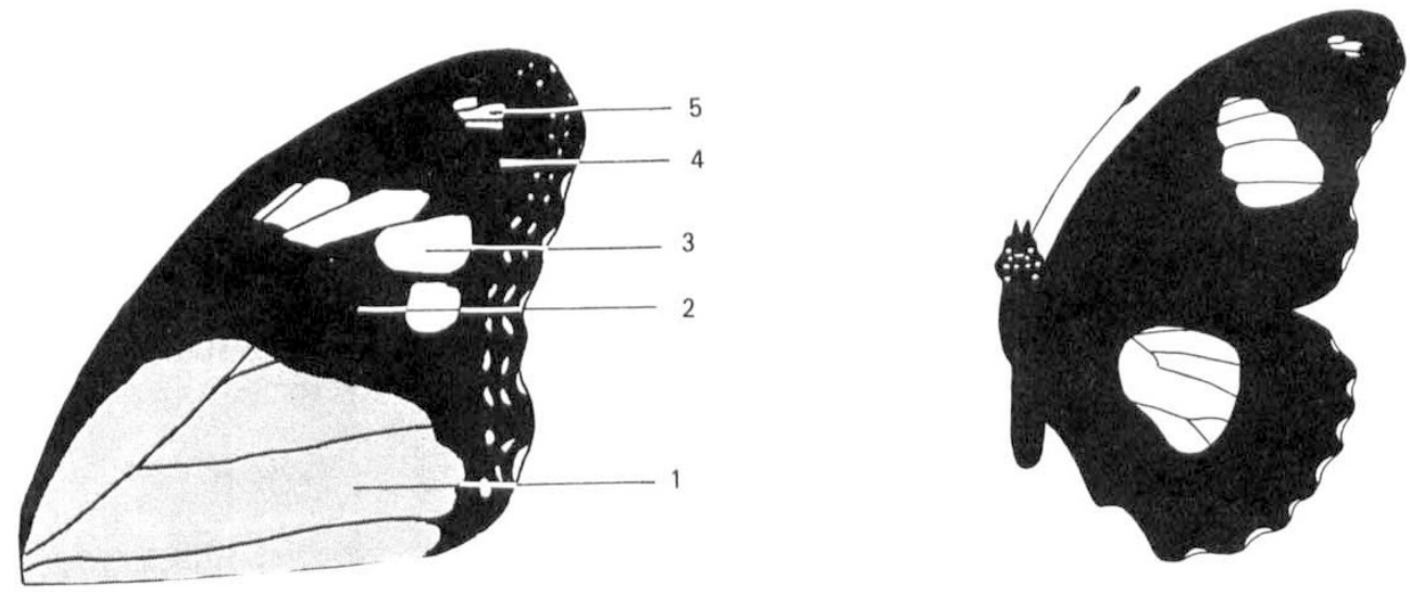

Figure 1 (Left) The five areas of the Hypolimnas misippus female forewing described in the text. The example illustrated is form misippus. The stippled area (1) is orange. Areas 2 and 4 are black, areas 3 and 5 white as shown. (Right) The monomorphic male is black and white except that the white area on the hindwing is ringed with irridescent purple. 

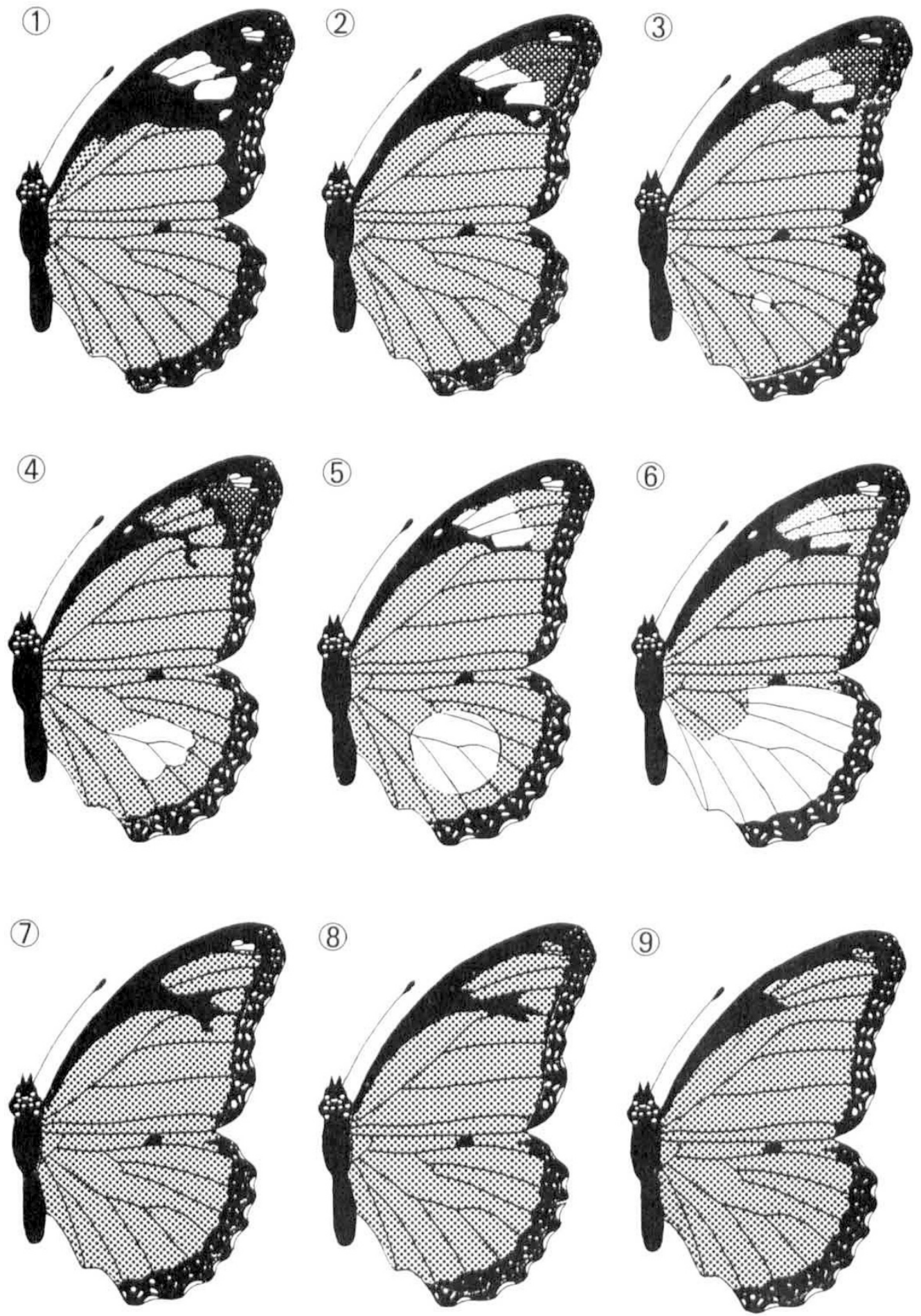

Figure 2 The forewing phenotypes of Hypolimnas misippus. The black $(b l)$ and white $(w)$ areas are as shown. Dark stipple indicates brown $(b r)$, medium stipple, orange $(c)$ and pale stipple, pale orange $(p)$. The phenotypes are: 1. blw (form misippus); 2 . brw; 3. brp; 4. bro; 5. ow; 6. op; 7. oo with aree 2 black and area 5 white; 8. oo with area 2 black; 9. oo. Forms 7-9 are of inaria phenotype whereas all the forms 2-9 are of inaria $(\mathrm{mm})$ genotype. Variation in the extent of hindwing white is shown in 3-6: Number 3 is scored as brp2, number 4 as bro 3 and numbers 5-6 as ow 5 and op 8 respectively (see text). 
Table 1 Classification of the female phenotypes of Hypolimnas misippus

\begin{tabular}{|c|c|c|c|c|c|c|c|}
\hline \multicolumn{5}{|c|}{ Aree of forewing (fig. 2) } & \multicolumn{3}{|c|}{ Phenotypic categories } \\
\hline 1 & 2 & 3 & 4 & 5 & Edmunds (1969) & Pierre (1973) & This paper \\
\hline$o$ & $b l$ & $w$ & $b l$ & $w$ & $b l w$ & misippus & misippus \\
\hline$o$ & $b l$ & $w$ & $b r$ & $w$ & $b r w$ & & \\
\hline$o$ & $b l$ & $w$ & $o$ & $w$ & ow & & intermediate \\
\hline$o$ & $b l$ & $p$ & $b r$ & $w$ & $b r p$ & immima & inaria \\
\hline$o$ & $b l$ & $p$ & $o$ & $w$ & $o p$ & & \\
\hline$o$ & $b l$ & $o$ & $b r$ & $w$ & bro & & \\
\hline$o$ & $b l$ & $o$ & $o$ & $w$ & $o o$ & & \\
\hline$o$ & $b l$ & $o$ & $o$ & $o$ & $o o$ & inaria & inaria \\
\hline$o$ & $o$ & $o$ & $o$ & $o$ & $o o$ & & \\
\hline
\end{tabular}

$o=$ orange, $b l=$ black, $b r=$ brown, $p=$ pale (orange), $w=$ white.

expression of the "inaria" forewing gene to produce the various intermediate phenotypes. The gene giving hindwing melanism also produces a "misippus" ( $b l w)$ or near-"misippus" ( $b r w)$ forewing and is almost completely epistatic to the "inaria" gene (Smith and Gordon, in prep.).

\section{RESULTS}

One hundred and sixty-one broods were analysed, of which 23 gave no segregation, 13 segregated for forewing colour only, 57 hindwing colour only and 68 for both fore and hindwing. The breakdown takes account of a few broods where contamination is clear. Occasional contamination resulted from the presence of eggs or small larvae on foodplant gathered from the field. In this paper we are concerned only with the inheritance of forewing colour. All broods in which either the female parent or a proportion of the female offspring displayed hindwing melanism are excluded as this character also affects the forewing.

Sixty non-melanic broods gave no segregation for forewing colour. In 28 broods, where the female parent was misippus, all the progenies were blw (misippus) $(n=1493)$. A further 16 broods from non-"misippus" or inarie females also produced entirely misippus offspring $(n=881)$. Intermediate phenotypes were absent from all these broods indicating that the "misippus" character behaves as a complete dominant to "inaria". The results also suggest that the intermediate phenotypes are unlikely to be heterozygotes. Sixteen broods from non-"misippus" parents produced entirely non"misippus" progeny $(n=509)$. We conclude from these results that there is a dominant allele $M$, giving the "misippus" forewing, and a recessive allele $m$ which gives non-"misippus" or "inaria" forewings in the homozygous state.

Of the segregating broods, the $19 \mathrm{~F} 2$ broods (table 2) give an excellent fit to $3: 1$ and can be accepted as homogeneous. As all were obtained from misippus parents, they confirm the dominance of this character over inaria. Eleven broods of the 59 (backcross + F2) segregating for forewing fit both $3: 1$ and $1: 1$ hypotheses. Statistically, this is not surprising and their inclusion, according to best fit, in either the F2 (6) or backcross (5) series, produces no significant heterogeneity.

The 40 backcross broods (table 3) are homogeneous $(0.7>P>0.5)$ and $\sum \chi_{(40)}^{2}$ is not significant $(0 \cdot 5>P>0 \cdot 3)$. However $\chi_{(1)}^{2}$ for the total progeny test is highly significant $(0.01>P>$ $0 \cdot 001$ ) and indicates an overall bias to misippus which is small and goes mainly undetected in individual broods. Twenty-six broods are biased in the "misippus" direction compared with only 10 to inaria and this imbalance is itself significant $\left(\chi_{(1)}^{2}=7 \cdot 111 ; 0 \cdot 01>P>0 \cdot 001\right)$. Three individual broods show a significant departure from $1: 1$, this being no surprise in such a long series. Two of these broods (S136, N151) in fact fit 3:1 but they must be backcross results as the female parents were inaria. All three broods segregated either 1:0 (2) or $1: 1$ (1) for white hindwing and 20 of the remaining 23 broods showing bias to misippus also had various proportions of whites among the progeny. We believe the bias is due to variable epistasis, over the "inaria" forewing genotype $(\mathrm{mm})$, exercised by the genes controlling hindwing white. These genes tend to convert the forewing pattern into the misippus phenotype. The bias thus results from misclassification rather than differential viability. 
Table 2 Broods of $H$. misippus segregating $3: 1$ for forewing colour

\begin{tabular}{|c|c|c|c|c|c|c|}
\hline \multirow[b]{2}{*}{ Brood number } & \multirow{2}{*}{$\begin{array}{l}\text { Maternal } \\
\text { phenotype }\end{array}$} & \multicolumn{5}{|c|}{ Female progeny } \\
\hline & & Hindwing colour & misippus & inaria & $N$ & $\chi^{2}$ \\
\hline G4 & blw5 & $w$ & 7 & 4 & 11 & 0.758 \\
\hline G6 & blw0 & $o$ & 25 & 5 & 30 & $1 \cdot 111$ \\
\hline G23 & $b l w 0$ & $o \& w$ & 15 & 3 & 18 & 0.667 \\
\hline G27 & $b l w 1$ & $o \& w$ & 82 & 27 & 109 & 0.009 \\
\hline G41 & blw3 & $o \& w$ & 50 & 26 & 76 & 3.439 \\
\hline G53 & blw3 & $w$ & 45 & 16 & 61 & 0.049 \\
\hline G58 & blw1 & $o \& w$ & 85 & 22 & 107 & $1 \cdot 125$ \\
\hline G63 & $b l w 2$ & $w$ & 70 & 25 & 95 & $0 \cdot 088$ \\
\hline G65 & $b l w 0$ & $o \& w$ & 46 & 17 & 63 & $0 \cdot 132$ \\
\hline G83 & $b l w 2$ & $o \& w$ & 55 & 19 & 74 & 0.018 \\
\hline G102 & $b l w 0$ & $o \& w$ & 26 & 11 & 37 & 0.441 \\
\hline G105 & blw 4 & $w$ & 64 & 20 & 84 & $0 \cdot 063$ \\
\hline S124 & blw2 & $o$ & 13 & 6 & 19 & 0.439 \\
\hline S131 & $b l w 2$ & $o \& w$ & 17 & 7 & 24 & $0 \cdot 222$ \\
\hline $\mathrm{S} 138$ & $b l w 5$ & $o \& w$ & 19 & 4 & 23 & 0.710 \\
\hline S140 & blw2 & $o \& w$ & 51 & 20 & 71 & $0 \cdot 380$ \\
\hline K143 & $b l w 0$ & $o \& w$ & 37 & 17 & 54 & $1 \cdot 210$ \\
\hline N149 & $b l w 0$ & $o \& w$ & 13 & 6 & 19 & 0.439 \\
\hline N155 & $b l w 4$ & $o \& w$ & 14 & 8 & 22 & 1.515 \\
\hline$\sum \chi_{(19)}^{2}$ & & & & & & $12 \cdot 815$ \\
\hline Total progeny & & & 734 & 263 & 997 & 1.011 \\
\hline Heterogeneity $\chi_{(18)}^{2}$ & & & & & & 11.804 \\
\hline
\end{tabular}

Notes: (1) Brood prefixes are: $\mathrm{G}=$ Ghana, $\mathrm{N}=$ Nigeria, $\mathrm{M}=$ Malawi (Nyasaland), $\mathrm{S}=$ Sierra Leone, $\mathrm{T}=$ Tanzania (Tanganyika), $\mathrm{SA}=$ South Africa, $\mathrm{K}=$ Kenya in this and the following table. (2) Under 'hindwing colour', $o=$ orange and $w=$ white.

The epistasis will be examined in more detail in subsequent papers. At this point we are concerned only to substantiate our assertion that it is responsible for misclassification for forewing phenotypes. The data in table 4 show that the presence of hindwing white is accompanied by a significant shift of forewing colour pattern away from $o o$ to brw. Of the $\mathrm{mm}$ butterflies with white hindwings, 74.5 per cent had intermediate forewings and 22.5 per cent were brw, compared with 48.0 per cent and 3.3 per cent respectively for those with orange hindwings $\left(\chi_{(2)}^{2}=205 \cdot 7 ; P<0 \cdot 001\right)$.

\section{DISCUSSION}

The results leave no doubt that the $M$ locus is autosomal. In butterflies, the female is the heterogametic sex. Therefore, Y-linkage is easily ruled out as all female progeny would necessarily resemble their mothers, from whom they receive their Y chromosome. Segregation would occur only if the locus involved was located on a homologous segment present on both $\mathrm{X}$ and $\mathrm{Y}$ chromosomes but no case of this type has been recorded for Lepidoptera. On the other hand, as the $\mathrm{X}$ chromosome of the female must come from her father, $1: 1$ segregations in female progenies are expected to occur for X-linked loci but $3: 1$ ratios, common in our broods, are not possible. It is clear, therefore, that the $M$ locus is autosomal but sex-controlled to the female as in the femalelimited polymorphism in $\mathrm{H}$. bolina (Clarke and Sheppard, 1975).

The results also establish that the "misippus" pattern $(b l w)$ is fully dominant to "inaria" $(o o)$. All the intermediate phenotypes ( $b r w, b r p, b r o, o w$, $o p)$ are genetically "inaria". These latter forms, which comprise the variety immima of Bernardi (1959) and Pierre $(1973,1980)$, have no genetic status. Some broods (e.g., K141) contained entirely oo progeny although the female parent was brw and close to misippus in appearance. In contrast, blw mothers never produced all inaria progeny. On the other hand, broods T160 and T161, both from $o p$ parents, consisted almost entirely of intermediates. There is a positive correlation between white on the hindwing and intermediate forewing in field collected specimens (Edmunds, 1969; Smith, 1976; Gordon, 1982) and the same effect is clear in our broods (table 4). This suggests that the expression of the "inaria" pattern in $\mathrm{mm}$ butterflies is affected by other genes, the primary effect of which is on the hindwing but which also interact 
Table 3 Broods of $H$. misippus segregating 1:1 for forewing colour

\begin{tabular}{|c|c|c|c|c|c|c|}
\hline \multirow[b]{2}{*}{ Brood number } & \multirow{2}{*}{$\begin{array}{l}\text { Maternal } \\
\text { phenotype }\end{array}$} & \multicolumn{5}{|c|}{ Female progeny } \\
\hline & & Hindwing colour & misippus & inaria & $N$ & $x^{2}$ \\
\hline G1 & op 0 & $o \& w$ & 10 & 11 & 21 & $0 \cdot 048$ \\
\hline G3 & blw5 & $w$ & 16 & 20 & 36 & $0 \cdot 444$ \\
\hline G14 & $\circ o 0$ & $o \& w$ & 21 & 12 & 33 & $2 \cdot 455$ \\
\hline G15 & ow 4 & $o \& w$ & 16 & 14 & 30 & $0 \cdot 133$ \\
\hline G17 & op 1 & $o \& w$ & 67 & 63 & 130 & $0 \cdot 123$ \\
\hline G18 & op 0 & $o \& w$ & 60 & 63 & 123 & 0.073 \\
\hline G22 & op 5 & $o \& w$ & 17 & 16 & 33 & $0 \cdot 030$ \\
\hline G25 & 000 & $o \& w$ & 33 & 31 & 64 & 0.063 \\
\hline G26 & $\circ o 0$ & $o \& w$ & 140 & 130 & 270 & $0 \cdot 370$ \\
\hline G29 & $b r w 2$ & $o \& w$ & 19 & 17 & 36 & $0 \cdot 111$ \\
\hline G32 & brw3 & $o$ & 33 & 21 & 54 & 2.667 \\
\hline G35 & brp0 & $o$ & 16 & 12 & 28 & 0.571 \\
\hline G37 & $b r p 0$ & $o$ & 21 & 26 & 47 & 0.532 \\
\hline G51 & op 4 & $o \& w$ & 96 & 71 & 167 & $3 \cdot 743$ \\
\hline G54 & op 4 & $o \& w$ & 41 & 42 & 83 & 0.012 \\
\hline G59 & blw0 & $o \& w$ & 31 & 39 & 70 & 0.914 \\
\hline G60 & op 4 & $o \& w$ & 35 & 45 & 80 & $1 \cdot 250$ \\
\hline G76 & brp 1 & $o \& w$ & 25 & 19 & 44 & $0 \cdot 818$ \\
\hline G79 & oo0 & $w$ & 14 & 15 & 29 & 0.034 \\
\hline G81 & blw0 & $o \& w$ & 29 & 30 & 59 & 0.017 \\
\hline G84 & $b r w 1$ & $o \& w$ & 13 & 7 & 20 & $1 \cdot 800$ \\
\hline G85 & bro0 & $o$ & 6 & 6 & 12 & 0.000 \\
\hline G88 & $b l w 0$ & $o \& w$ & 8 & 6 & 14 & 0.286 \\
\hline G98 & $b l w 1$ & $o \& w$ & 58 & 46 & 104 & $1 \cdot 385$ \\
\hline G103 & blw6 & $o \& w$ & 10 & 9 & 19 & 0.053 \\
\hline G115 & brp 3 & $o \& w$ & 30 & 17 & 47 & $3 \cdot 596$ \\
\hline S127 & $\circ o 0$ & $o \& w$ & 21 & 26 & 47 & 0.532 \\
\hline $\mathrm{S} 128$ & $0 o 0$ & $o \& w$ & 4 & 4 & 8 & 0.000 \\
\hline S136 & oo 4 & $w$ & 20 & 7 & 27 & $6 \cdot 259^{*}$ \\
\hline S137 & blw0 & $o \& w$ & 56 & 35 & 91 & $4 \cdot 846^{*}$ \\
\hline S139 & 003 & $o \& w$ & 11 & 9 & 20 & $0 \cdot 200$ \\
\hline N144 & $b l w 0$ & $o \& w$ & 22 & 19 & 41 & $0 \cdot 220$ \\
\hline N146 & $o o 0$ & $o \& w$ & 4 & 7 & 11 & 0.818 \\
\hline N147 & blw3 & $o \& w$ & 16 & 11 & 27 & 0.926 \\
\hline N150 & $0 o 0$ & $o \& w$ & 16 & 14 & 30 & $0 \cdot 133$ \\
\hline N151 & ow 10 & $w$ & 21 & 9 & 30 & $4 \cdot 800^{*}$ \\
\hline M152 & blw0 & $o$ & 55 & 42 & 97 & $1 \cdot 742$ \\
\hline SA153 & bro2 & $o \& w$ & 4 & 4 & 8 & $0 \cdot 000$ \\
\hline N154 & $b l w 0$ & $o \& w$ & 17 & 16 & 33 & 0.030 \\
\hline T159 & blw 3 & $o \& w$ & 15 & 9 & 24 & 1.500 \\
\hline$\sum \chi_{(40)}^{2}$ & & & & & & $\overline{43 \cdot 535}$ \\
\hline Total progeny & & & 1147 & 1000 & 2147 & $10.065^{*}$ \\
\hline Heterogeneity $\chi_{(39)}^{2}$ & & & & & & $33 \cdot 470$ \\
\hline
\end{tabular}

* Indicates that segregation rejects $H_{o}$ by $P<0 \cdot 05$.

epistatically with the M locus. Indeed, the forewing segregations in broods S136 and N151, from oo 4 and ow 10 parents respectively, all the progeny of which had substantial amounts of hindwing white, suggest that many of the offspring were phenotypically "misippus" despite being of "inaria" genotype. These two broods, segregating 20:7 and $21: 9$, fit $3: 1$ satisfactorily but reject $1: 1$. However, they must be backcrosses as they came from inaria parents. This phenomenon occurred on a smaller scale in many other broods and no doubt explains the excess of "misippus" offspring found in the progeny test on backcross broods. The F2 broods are less prone to this source of bias as only $\frac{1}{4}$ of the progeny is genetically "inaria" and they show no deviation from expectation in the progeny test.

Our data do not support Ford's (1953) general conclusion that F2 segregations for misippus: inaria approach $2: 1$. The four broods he analysed segregated 99 misippus to 47 inaria, an excellent 
Table 4 The effect of hindwing white on the forewing phenotype of $\mathrm{mm}$ (inaria) butterflies in the broods detailed in tables 2 and 3

\begin{tabular}{|c|c|c|c|c|}
\hline $\begin{array}{l}\text { Hindwing } \\
\text { phenotype }\end{array}$ & $b r w$ & $\begin{array}{l}\quad \text { Forewing } \\
\text { Other } \\
\text { intermediate }\end{array}$ & enoty & Total \\
\hline white & 194 & 448 & 220 & 862 \\
\hline orange & 28 & 384 & 446 & 858 \\
\hline Total & 222 & 832 & 666 & 1720 \\
\hline
\end{tabular}

$\chi_{(2)}^{2}=205.7 ; P<0.001$.

fit to $2: 1$ without significant heterogeneity, and he believed this result indicated selection against the homozygous dominant genotype. By comparison with our broods, 11 of which formally fit $2: 1$, but introduce no heterogeneity when incorporated into the F2 and backcross series, the correct interpretation for Ford's results is possibly that they were backcrosses showing a deviation towards the "misippus" phenotype due to epistasis exercised by genes at other loci. In particular, two of our $2: 1$ broods (S136, N151) must be backcrosses as they had inaria mothers, both carrying extensive hindwing white, a character which also appeared in all the progeny. Two further clear $1: 1$ broods (G3, G79) in which the progeny had a high mean score for white segregated normally, a fact which emphasises the variability of the epistasis.

Interactions between fore and hindwing phenotypes may be further investigated in individual broods which segregated for one character only. Two broods (S124, M152) segregated at the M locus but all had orange hindwings: segregation for forewing was absolutely discrete as all progeny were either $b l w$ or $o o$. On the other hand, two broods (S136, N151) in which all offspring had white hindwings but segregated at the $\mathrm{M}$ locus, contained the full range of intermediate forewings in the inaria-alcippoides $(\mathrm{mm})$ fraction. The difference between the two pairs of broods supports the hypothesis that genes giving white on the hindwing exercise variable epistasis over the $\mathrm{M}$ locus in the $\mathrm{mm}$ genotype.

Many broods (not detailed here) segregated for orange:white hindwing but were all $M$ ("misippus" forewing): the full range of hindwing classes was represented but not a single intermediate forewing (except for a few obvious contaminants). Finally, several broods (not detailed here) had entirely $\mathrm{mm}$ forewings but segregated for hindwing. The white progeny in most of these broods contained many intermediate forewing phenotypes although in two cases intermediates were few (S126) or absent (K141). The two exceptional broods show that hindwing white is not invariably epistatic over the "inaria" forewing.

To summarise, the $M$ allele gives orange over the fore and hindwings except for the black apical half of the forewing and the three white areas. The $m$ allele, which is fully recessive, extends the orange pigment over the entire forewing excepting only the black margins. Some, but not all, the genes giving hindwing white are epistatic to the $\mathrm{M}$ locus in the $\mathrm{mm}$ genotype, tending to prevent total displacement of black and/or white on the forewing and sometimes producing a general dilution of orange (broods T160, T161).

It would be premature at this point to embark on a discussion of the misippus-inaria polymorphism in relation to mimicry and sexual selection. Suffice it to say that the widespread occurrence of variable intermediates in the broods described here, reared in many different parts of Africa, suggests that factors other than close resemblance to forms aegyptius and dorippus of D. chrysippus may have selective value (Smith, 1976; Gordon, 1982). It is clear that earlier investigators (e.g. Pierre, 1973, 1980; Ford, 1953, 1975), with the notable exception of Edmunds (1969), have seriously underestimated the frequency, geographical range and, hence probably, the importance of these forms. The intermediate phenotypes are often abundant and may even be the most ubiquitous forms (Smith, 1976). Their high frequency and diversity, especially at times of peak density, suggests that apostatic selection may be operating.

Acknowledgments We are much indebted to the late Josiah A. Unamba for his pioneering genetical work in Sierra Leone and to Professor D. F. Owen for suggesting the topic, supervising Unamba's Ph.D. and allowing us to publish his results along with our own. The late Professor P. M. Sheppard F.R.S. made many pertinent comments on Unamba's work. Professor Sir Cyril Clarke F.R.S. and Dr. R. I. Vane-Wright made helpful criticisms of an earlier draft of this paper. One of us (I.J.G.) thanks Professor Ray Kumar who supervised his Ph.D. research which made the most substantial contribution to the results in this paper. Finally, we thank the Heads of the Zoology Departments in which we have worked in various parts of Africa, Professor D. F. Owen, University of Sierra Leone (D.A.S.S.), Professor A. S. Msangi, University of Dar es Salaam, Tanzania (D.A.S.S.) and Professor J. S. Djangmah, University of Cape Coast, Ghana (I.J.G.).

\section{REFERENCES}

BERNARDI, G. 1959. La variation géographique du polymorphisms chez les Hypolimnas du continent africain. Bulletin de l'I.F.A.N., 21. 
CLARKE, C. A. AND SHEPPARD, P. M. 1959. The genetics of Papilio dardanus Brown. I. Race Cenea from South Africa. Genetics, 44, 1347-1458.

CLARKE, C. A. AND SHEPPARD, P. M. 1960 a. The genetics of Papilio dardanus Brown. II. Races Dardanus, Polytrophus, Meseres and Tibullus. Genetics, 45, 439-457.

CLARKE, C. A. AND SHEPPARD, P. M. 1960 b. The evolution of dominance under disruptive selection. Heredity, 14, 73-87.

CLARKE, C. A. AND SHEPPARD, P. M. 1962. The genetics of the mimetic butterfly Papilio glaucus. Ecology, 43, 159-161.

CLARKE, C. A. AND SHEPPARD, P. M. 1963. Interactions between major genes and polygenes in the determination of the mimetic pattern of Papilio dardanus. Evolution, 17, 404-413.

CLARKE, C. A. AND SHEPPARD, P. M. 1972. The genetics of the mimetic butterfly Papilio polytes L. Phil. Trans. R. Soc. Lond. $B, 263,35-70$.

CLARKE, C. A. AND SHEPPARD, P. M. 1975. The genetics of the mimetic butterfly Hypolimnas bolina (L). Phil. Trans. R. Soc. Lond. $B, 272,229-265$.

CLARKE, C. A., SHEPPARD, P. M. AND THORNTON, I. W. B. 1968. The genetics of the mimetic butterfly Papilio memnon L. Phil Trans. R. Soc. Lond. B, 254, 37-89.

EDMUNDS, M. 1969. Polymorphism in the mimetic butterfly Hypolimnas misippus L. in Ghana. Heredity, 24, 281-302.

FORD, E. B. 1953. The genetics of polymorphism in the Lepidoptera. Advances in Genetics, 5, 43-87.

FORD, E. B. 1975. Ecological genetics. Chapman \& Hall, London.

GORDON, I. J. 1982. The biology of Danaus chrysippus (Lepidoptera, Danaidae) and its mimics in Ghana. Ph.D. Thesis, University of Ghana.
MARSH, N. A., CLARKE, C. A., ROTHSCHILD, M. AND KELLETT, D. N. 1977. Hypolimnas bolina (L.), a mimic of danaid butterflies and its model Euploea core (Cram.) store cardioactive substances. Nature, 268, 726-728.

PIERRE, J. 1973. Etude du polymorphisme chez Danaus chrysippus (Linné) (Lepidopére: Danaide) pour modèle et Hypolimnas misippus (Linné) (Nymphalide) pour mime. Archives de zoologie expérimentale et générale, 114, 73-96.

PIERRE, J. 1976. Polymorphisme et mimétisme chez deux éspéces jumelles Acraea encedon et Acraea encedana (Lep., Acraeidae), Ann. Soc. Ent. France (N.S.), 12, 621-638.

PIERRE, J. 1980. Variation géographique du polymorphisme et du mimétisme de Danaus chrysippus et d'Hypolimnas misippus (lepidoptères Rhopalocères) en Afrique et en Asie. C.R. Soc. Biogéogr., 486, 179-187.

POUlton, E. B. 1908. Essays on evolution, 1889-1907. Clarendon Press, Oxford.

SMITH, D. A. S. 1976. Phenotypic diversity, mimicry and natural selection in the African butterfly Hypolimnas misippus L. (Lepidoptera: Nymphalidae). Biological Journal of the Linnean Society, 8, 183-204.

SMITH, D. A. S. 1984. Mate selection in butterflies: competition, coyness, choice and chauvinism. Vane-Wright, R. I. and Ackery, P. R. (eds.) Symposium of the Royal Entomological Society of London, 11, 225-244.

UNAMBA, J. A. 1968. Ecological genetics of the butterfly Hypolimnas misippus. Ph.D. Thesis, University of Sierra Leone, Freetown. 